\title{
PARTLY FOLKSY, SOMETIMES SMIRKING: A NEW TRANSLATION OF AUGUSTINE'S CONFESSIONS
}

\author{
D van Schoor (Rhodes University)
}

\begin{abstract}
The translator and poet Sarah Ruden published her new and in some ways quite original translation of Augustine's Confessions in 2017. In a fighting introductory essay she explains her position which she characterises as maverick. She contrasts her own work against other translations, which she regards as more traditional. Ruden makes provocative claims about the allegedly conventional interpretations, which, relative to hers she argues, can work to obscure rather than convey what the Bishop of Hippo intended his contemporary audience to understand. This essay forms a reflection on her claims and sets some of her passages against the original Latin and those of other modern English translators. While Ruden's is a welcome contribution to a well populated field of translations into modern languages, her claims and strategies are not found to be always entirely judicious.
\end{abstract}

Keywords: Augustine; Confessions; Latin; English translation; Sarah Ruden.

\section{Sine praedicante}

At Confessions 1.1 Augustine is rhetorically asking God, to whom his work is addressed, how he ought best to begin:

da mihi domine, scire et intellegere, utrum sit prius invocare te an laudare te. sed quis te invocat nesciens te? aliud enim pro alio potest invocare nesciens. an potius invocaris ut sciaris? quomodo autem invocabunt, in quem non crediderunt? aut quomodo credent sine praedicante?

Sarah Ruden's new translation is a self-consciously updating one, it breaks with conventions in several ways and aims to redeem Augustine as 'literary artist', the 'poetic creator' (p. xxviii) and in its way efface 'any impression of Augustine - in this work, anyway - as a plodder or systematizer rather than a poetic, organically branching, rather whimsical author' (p. xl). There is a long tradition of reading and translating Augustine, devoted scholars and readers have reflected on his works for many centuries. To give a sample of how many English readers, since the $17^{\text {th }}$ century, would first have encountered this opening passage, here are the above lines rendered by William Watts from his translation first published in 1631, (he had relied in some measure on Sir Tobie Matthew's 1624 translation, even 
while referring to Matthews as 'the papist' — readings of Augustine have long been contentious): ${ }^{1}$

Grant me, Lord, to know and understand what I ought first to do, whether call upon thee, or praise thee? and which ought to be first, to know thee, or to call upon thee? But who can rightly call upon thee that is yet ignorant of thee? for such an one may instead of thee call upon another. Or art thou first called upon that thou mayest so come to be known? But how then shall they call on him, in whom they have not believed? and how shall they believe without a preacher [sine praedicante]?

When it comes to works from Antiquity, the reader without Latin or Greek has to take a translator's word for it, but fortunately there are many translations to choose from and weigh against one another these days. Perhaps, the most important way in which a translator can serve this particular writer is to emulate in some way his gift for expressing the tension, the inward drama, which was the very contents of his life as he regarded it. ${ }^{2}$ Augustine's Confessions is a work memorably marked by such tensions and hesitations and a deep sensitivity to the reality of ignorance, of the self as a shadowy thing only partially illuminated by sacred truths that came from God and the hard-won insights of self-scrutiny. The heart is afflicted by lifelong disquiet, until it finds rest in God, inquietum est cor nostrum donec requiescat in te. In Confessions, these tensions and anxieties are vividly dramatized in the form of an extended apostrophe, by a man who defines himself through his formative doubts, questioning, his active and continuous intellectual and spiritual struggling.

These struggles constitute the voyage towards his God's grace, the movement towards salvation. His is a lifelong dialogue of inquiry and interpretation of himself, as if he constituted a living text undergoing a delicate, ongoing exegesis, whose chapters' meanings are illuminated by earlier chapters. This self - Augustine - is an unfolding story, acts and responses that form a Life, whose illuminations have been foreshadowed in its earlier instantiations, rather as Sacred Scripture is an account of new truths foreshadowed in revelations and narrations past.

This tension - between past and present, understanding and ignorance, spiritual yearning and actual condition of hesitation and incomprehension - is in

See Rouse's introduction to the Loeb edition of Watts' translation, 1912.

Cf. Brown 2000 [1967]:172-3: 'It was a traditional theme to expose one's soul to the commands of God, knowing He "searched the hearts of men". But it was most unusual to insist, as Augustine does, that no man could ever sufficiently search his own heart, that the "spreading, limitless room" was so complex, so mysterious, that no one could ever know his whole personality; ...'. 
part the greatness of the work and the man. Its complexity and liveliness issue from the strongly felt sense of difficulty and a deeply intimate life of thought cogently conveyed but finely retaining every subtlety of colouring. Many readers have experienced this simultaneous power and nuance of the work, which has the immediacy of a living internal voice, the volume and presence of consciousness itself.

No sense of doubt, tension or hesitation, by contrast, is expressed by the intrepid translator Sarah Ruden in the introduction to her bold, new translation. It is, rather, with a surprising sureness of step that she sets about the notoriously complex task of offering another translation, among many, of this fresh 1600-yearold voice. She suggests that, finally, it has found the translator - in her impartiality, freedom from political correctness and unencumberance by theological prejudice and tiresome scholarly practice ${ }^{3}$ - it finally deserves.

It is a view of her work apparently shared by none other than J M Coetzee. It is worth citing the recommendation to which he lends his distinguished name because it raises very great expectations in the reader and potential buyer of this version and to the scholar interested in Augustine it is an enticement that cannot be ignored. Coetzee's 'advance praise for Sarah Ruden's translation' runs:

Based on fresh insights into what it meant in Augustine's day to write good prose, Sarah Ruden has produced a version of Confessions that speaks to us clearly and directly and may well reflect Augustine's meaning more accurately than any other translation hitherto.

The prospect of 'fresh insights' into such an enduringly powerful work, by the most influential African writer in history is always going to excite. 'What it meant to write good prose' in Late Antiquity is of course a fascinating topic in itself and it is true that Ruden's work speaks mostly clearly and very directly. In fact, both the chief merit and most questionable characteristic of Ruden's Confessions is the vividness, after which above all she seems to have been striving. Coetzee simply goes too far, however, with the injudicious ('may well' notwithstanding) 'reflect Augustine's meaning more accurately than any other translation hitherto'. The $20^{\text {th }}$ and $21^{\text {st }}$ century reader has been living in a golden age of scholarship and the number of biographies, histories of the period and translations of Augustine into

For example, 'I fill in a lot of blanks, believing it to be very tiresome behaviour to send readers to footnote after footnote just so that I can try to simulate a degree of cursoriness [she means Augustine's tendency to refer to persons or groups with pronouns rather than repeating their names] that can't exist in formal English writing except under the headings "careless" and "bad". Any representation of Augustine that gives that impression is not authentic'. (pp. xxxviii-ix). 
English, not to mention the other modern languages, leaves us truly spoiled for choice. If this is a competition, it is stiff.

For those with Latin or who wish for detailed commentary, there is the recent but already authoritative text edited by $\mathrm{J} \mathrm{J}$ O'Donnell with learned and highly regarded notes, (Oxford, 1992, freely available online). As for translation into English, in the last quarter-century alone, we can look to Chadwick for OUP (1991), the widely admired version of Boulding (Hodder \& Stoughton, 1997), Wills' Penguin translation (2004), Hammond's bilingual Loeb (2016, a replacement of Watts' version which, updated by Pusey in the $19^{\text {th }}$ century, had served the Loeb Library up to 2016). Frank Sheed's 1942 translation has been greatly respected and it is the one through which many English speakers will first have come to know Augustine. It possibly retains for that reason a special place in their relationship with the writer and his work, (it was my own father's - born 1923 - much loved translation). Sheed's appeared in a second edition in 2006 with an introduction by Peter Brown and notes and appendix by Michael Foley. ${ }^{4}$ With its timelines and chapter headings, its maps, suggestions for further reading, concise opening essay, discreet footnotes and illuminating glossary of select terms (see for example the excellent note on 'typological exegesis' pp. 333-4), it is hard to imagine a piece of work more well judged and helpful to the receptive reader. Against all of these Ruden's, it is a pity to report, suffers by comparison despite the special pleading to 'professors who may be inclined to anathematize my translation because it is different' in her introduction (p. xxvi). It is not that her translation is 'different' that is problematic and no one should find her translation 'anathema' (note the light pre-empting of anything like ecclesiastical authority in the term). The problem is how it is different.

It has been a golden age also for books about Augustine and the world of Late Antiquity: from John Burnaby's Amor Dei (1938, 'the greatest of intellectual biographies', in Chadwick's estimation); Pierre Courcelle's watershed study of Confessions (1950, expanded 1968); to the great Peter Brown's contributions to the field over a very distinguished career, most pertinently Augustine of Hippo - A biography (1967, and the new edition with epilogue discussion of new evidence, 2000). The reader who came to Augustine through Ruden's new Modern Library edition would never have an inkling. On Augustine scholarship we hear only, in the last line of her acknowledgements (p. 484), that she is 'particularly indebted also to Robin Lane Fox for Augustine: Conversion to Confessions (2015)'.

Sheed 2006.

See the unfavourable review of this work by the Augustine translator and scholar Garry Wills in The New York Review of Books (January, 142016 issue) and the ensuing exchange of letters, New York Review of Books (March, 102016 issue). 
Now, her mandate may have been to produce an 'accessible' translation, in updated English for this modern library of classics and to avoid encumbering the 'general reader' - but there is no such thing — with the onera of professional scholarship. But Aurelius Augustine, probably ethnically Berber, a North African educated in the Latin lingua franca of the $4^{\text {th }}$ century Roman Empire, a man who lived 1600 years ago: is this someone to whom one really wishes to pretend we can have absolutely direct access? If we believe we can meet him unimpeded, have we in some measure been taking in by the rhetorical power of his directly addressing first person voice? Imaginably, most readers of this will be educated, more or less critical, humanist, post-Enlightenment, post-industrial, late Moderns. We, perhaps, are just those ones who are ignorant - nesciens - of Augustine's god and the nature of the relationship with that god evoked in the opening of Confessions. We must allow that we are just such as those who 'have not believed' - non crediderunt - of whom the writer wonders how they can begin to recognise what they have to do with here. How will we recognise this god, and how exactly will we - different kinds of person that we are - even recognise this man? What do we forfeit when we come to Augustine without a preacher - sine praedicante without explanation, exegesis, interpretation? Too much I worry.

New translations of important works ought always to be welcomed and we may be thankful to Ruden, for whatever the deficits of her work it is an accomplishment, which stimulates rich and fascinating questioning, an opportunity to revisit perennially important issues. One question that I have once again been asking myself in reflecting on this new version and her striking, somewhat polemical introductory essay, is what really translation is for and what its chief ambitions could or should be. Ruden explains her own motivations as follows (p. xxiii, my italics):

My main justification for this new translation, after several learned and serviceable ones have become established, is the previously hidden degree to which Augustine makes his life and ideas vivid in the style of his Latin. (The fusion of form and content in ancient literature has become something of a specialty for me in the course of translating a variety of Latin, Greek, and now Hebrew works.) In Augustine, the manner of presentation is especially compelling, because of his stress on beauty and joy on the one hand, and intellectual helplessness on the other ...

Translations are inherently failed enterprises. Jorge Luis Borges and Umberto Eco ingeniously drew the logical consequences of this inherent fallibility to their limits in their manner of $20^{\text {th }}$ century Alexandrians, poetae docti. Ruden pleads 
winsomely that if fail she must, she will 'fail openly' ${ }^{6}$ She concludes her opening remarks professing the hope that, at any rate, her work will provoke questions about translating, ('if they only provoke debate and thereby bring more attention to the task of translating this astonishing author, I'll count that as progress.' p. xli). Translation is a field to which she has given no little thought and productively devoted herself, having now published a half a dozen translations from Greek and Latin and a work on the craft itself, The face of water: A translator on beauty and meaning in the Bible, 2017.

There are many sensitive discussions about the nature and challenges of translating Augustine. Hammond is succinct and exemplary, the $2^{\text {nd }}$ edition of Sheed carries its learning very lightly and will constitute no heavy burden to the non-specialist reader, quite the contrary. Part of the trouble in Ruden is that implicit in her introduction and in the product of her ideas about translation itself is a radical, artificial and deleterious - one may even say Manichaean — cleft between the scholarly and the popular; the archaic, the learned, the theologically searching and historically sensitive on one hand and the immediate, accessible (that unfortunate word again, is it the burden we bear for the gift of the internet?), colloquial and up-to-date, on the other.

Ruden's is what one may call an enthusiastic interpretation, a product of the secularism that itself originates from Martin Luther's great revolution and its political and social consequences. One of the most very momentous acts in recent history was surely the act of translation by Luther and his fellow Protestants of the $16^{\text {th }}$ century. Modern, Western, Democratic, Late Capitalist individualist, consumers feel free to study and examine and evaluate all the things of this world in their own language and they believe this language, the codes and values, which that language represents and conveys is sufficient to disclose the meanings of all historical experience and trans-historical truths. The demotic is valid. Look how successful it has been, see how the world and its people submit to the irrepressible logic and imperial sway of modernity. The American language - and this is really a translation into American - some may fancy, is supremely commensurate to the task of revealing things as they truly are and have been. So much is predicated, for modern people, on the sureness of unmediated accessibility to reality and truth, there is so much optimism and self-belief in the Lutheran impulse to publish in order to redeem truth from the preserve of elites and the learned, the jealous authority of the clerics. We are surely entitled to take things our way. It is just this

6 'Obviously, Augustine is the author here, and gets his way; I'm not his schoolmarm ... He gets his lofty "heaven of heavens" ... Splitting differences this way produces splitting headaches, and in the end even the best efforts may look rather comical. But I would rather fail openly, fall while going out on a limb for him, than leave him up there with no chance.' (Ruden, p. xxx). 
bracing, impressive, sometimes in truth stirringly refreshing kind of hermeneutic impudence, which constitutes the great failing and, one must admit, an uncertain, occasional appeal in Ruden's translation.

\section{Bereshit}

'In the beginning ...' (Genesis); 'Wrath ...' (Iliad); 'Tell me of the man ...' (Odyssey); 'Arms and the man ...' (Aeneid); 'To tell of changed shapes, to new bodies my mind bears me ...' (Metamorphoses) - the opening words and lines of an ancient text typically announce its themes, establish the posture of the speaker or author and serve as prefatory and titular to the larger work. Augustine himself devotes Books 11 and 12 of the thirteen Books of Confessions to a discussion of just the first two verses of the book of Genesis. The man who once reflected as he emerged from his study that 'When a man hath done then he beginneth', was quite careful of the significance of openings and their relation to closings. His opening questions ripple out over the surface of the work, lending it a searching momentum, that finds a response, as we shall see, in the very closing words of the last book. The opening is a good place, then, for a close examination of the translation of an ancient work, Conf. 1.1:

Magnus es, domine, et laudabilis valde. magna virtus tua et sapientiae tuae non est numerus. et laudare te vult homo, aliqua portio creaturae tuae, et homo circumferens mortalitatem suam, circumferens testimonium peccati sui et testimonium quia superbis resistis; et tamen laudare te vult homo, aliqua portio creaturae tuae. tu excitas ut laudare te delectet, quia fecisti nos ad te et inquietum est cor nostrum donec requiescat in te.

Ruden's rendering of this passage serves very well, as does Augustine's proem to his larger work, as an example of her style and tone:

You are mighty, Master, and to be praised with a powerful voice: great is your goodness, and of your wisdom there can be no reckoning. Yet to praise you is the desire of a human being, who is some part of what you created; a human hauling his deathliness in a circle, hauling in a circle the evidence of his sin, and the evidence that you stand against the arrogant.

But still a mortal, a given portion of your creation, longs to extol you. In yourself you rouse us, giving us delight in glorifying you, because you made us with yourself as our goal, and our heart is restless until it rests in you.

In her introduction Ruden offers a glossary of selected Latin words explaining their root meanings and the ('non-standard' p. xxxi) choices she has made for their 
rendering into English, (offering such a glossary being fairly standard practice). Several of these glossed terms are in fact found in this passage. One of the very first words of Confessions is also one which Ruden has quite surprisingly broken with convention to translate anew. Dominus in Latin is typically given in English as 'Lord', familiar to hymn singers, prayers and light blasphemers everywhere, yet she, apparently unique amongst translators, renders it 'master'. 'Lord' she explains 'suggests a ruler or nobleman, or another political authority, or the enthroned God of imagery starting in the Hebrew Bible' (the Old Testament then), 'The Latin Bible's dominus, however, was far different in its contemporary associations' (p. xxxi). 'Lord' in English is to Ruden's ear essentially political, while 'master' captures the Roman etymology of dominus derived from domus 'household', i.e. owner of a household and its contents, including slaves: 'The unavoidable English translation seems to be "Master"' (p. xxxi) — although, strictly speaking, that has been quite deftly avoided for generations.

Two points here: on the nature of the English word 'lord' and its usage, and the accuracy of the claims about the restricted connotations for Augustine and his readers of the Latin dominus. The English 'lord' is not really be as restricted in its field of connotations as Ruden implies. One can after all be described as the 'lord of one's domain', implying sovereignty over oneself one's own destiny, a personal and even ethical dominion and not only one over public spaces or political orders. Terms like this are really unrestricted in their metaphorical elasticity. And yet, the allegedly unavoidable 'master', for all its rebarbative associations, is a translation, which if we are only honest we are compelled to accept, so Ruden (p. xxxiii):

This imagery, with its reminders of American plantation slavery, may be harsh and off-putting, but a translator must govern her distaste and try to make her author's thought and experience as vivid and sympathetic as it plainly was to his contemporaries. Otherwise, there can be no limits to the demands of a condescending, manipulative and anachronistic political correctness.

Fighting talk and perhaps we should be more thankful to the dauntless translators who govern their distaste for our sake in the name of authenticity, vividness and sympathy. But one is, somehow, given pause. Is Augustine's conception of God and his relationship to God really like that between slave-owners and slaves, or between the rogues and masters of Roman comedy (pp. xxxii-iii)? To be sure, the idea of an intertextual relationship with drama is intriguing, but not persuasively developed and besides the use of intertextual devices does not constitute submissive mimicry of earlier genres or forms, but dynamic and transformative acts of creativity and freedom. Augustine does not only passively deploy language but is one of the great transformers of meaning just as his account of conversion is 
the narration of a transformation, a deepening and extending of the meaning of his own past and present life and consequently also of the language through which he lived and knew his own life.

How, precisely, does the enforced servitude of American slaves bear resemblance to the willing service of Augustine - for Confessions is a study in the development of the will for — laudare te vult homo - the will towards god quia fecisti nos ad te - enacting the disposition of yearning for god, the love which, by this mysterious recursiveness, is also god's greatest gift to mortals. Confessions is occupied in a primary way with the motivations of the speaker, which he wishes to align at every level of himself with his God's own desire for His creations: the servi dei are members of a community of love, amor dei, not indentured submissively or fatefully, but defined by their yearning, their freely willing, their active not passive relationship with a god marked by His love and not characterised by compulsion.

There is a fundamental difference between servitude and service. The slave speaks 'Master', the servant willingly calls on his 'Lord' and volunteers himself in service, which is liberation from the chains of despotic, false masters: the flesh, specious teachings, nugatory entertainments. The distinction 'lord' and 'master' in English very serviceably helps us to retain and articulate this fundamentally important difference at the heart of Augustine's work and the Christianity he played such a role in defining.

Ruden seems concerned throughout to return us to the pristine, purportedly more true meaning of terms by hewing to their strictly etymological base and the roots on which tendril concepts later flourished. Perhaps then, we too may justifiably pause and consider the etymology of an English term like 'lord', unlike the Latinate 'master' - magister, magnus - a word of Germanic derivation. In Old English hläford is a composite of hläf and weard, 'loaf' and 'ward', the hläford or original 'lord' 'keeps the provisions', he is the head of the household, like the literal Roman dominus Ruden wishes us to have in mind here. Yet, who will argue on the basis of a fairly recondite etymology that we ought therefore to use 'lord' in English with more exactitude than we ordinarily do and jettison centuries of lived tradition, centuries through which the word has gathered, in the fascinating way that words do over time, so many accretions of meaning and connotation, appropriate for different social contexts, even if all those nuances are nourished from the radical sense of 'authority, power, responsibility, sovereignty, honour' and ultimately 'head of the house'?

The kyrios of the Greek New Testament, which the Latin translators of scripture rendered dominus, expresses a new kind of relationship, is the summons of a new kind of god and calls a new kind of human person into being. Whatever original, plain sense - peshat - these terms may have had in the historical durée 
of everyday usage, they are transformed by the new, revolutionary experience of Christianity, its new men like Augustine and its good 'News' - euangelium - the bold new message, which fulfils and transforms the established and apparently literal meanings of the subsequently 'Old Testament'. The language of Christian tradition and of Augustine's work, itself a pavement of citations, is inherently midrashic - searching, interpretative, figurative, discerning the hidden meaning, revealing the true relation - and forming a special, characteristic domain or register within the larger historical language and tradition.

If I have dwelt at length on the issue of dominus, Lord and Master, it is because in its innovation and defence, it serves as a kind of model example of Ruden's style of argument and the kind of priorities revealed through decisions and position. Servus, servire, 'slave' and 'to be a slave or to serve as a slave' form the next, connected item of her glossary. Again, we are told that we have no choice but to face the fact of the preciseness of historical usage, which Ruden has redeemed for us (p. xxxiii):

Whatever the looser versions of servitude in Palestine and in the Greek world, and the accordingly more nuanced and less harsh constructions possible for the relevant vocabulary in Hebrew and Greek, for the Romans, a slave was a slave, a piece of property, and any recent marginal legal rights slaves had obtained (partly under the influence of Christianity) had apparently not disturbed Augustine's view of a slave's fate as naturally abject (book 7, chapter 8). Augustine considers himself God's slave; he exists at God's pleasure, he exists only to do god's will, and only his death will deliver him from such an existence.

And yet Augustine's relationship with his God, one that Confessions chronicles and searches, is thankfully far more interesting than this suggests. His religion is not, as I have been arguing, one of submission but of love. Devotion to the body and transitory pleasure may indeed make for an abject life - and this is an account by a man entering middle age of his earlier, personal struggle to emancipate himself from values, philosophical ideas and appetites that he had felt so intensely from youth - but this is conceived as a life not a 'fate'. This life is defined, as the work itself seems conceived to express, by growth towards god and by qualities of free choosing - Augustine is one of the original articulants of what becomes a central issue in later Western philosophising, 'free will': liberum arbitrium voluntatis - and feeling, by a piety that springs from love, the desire that has learnt to desire rightly, the motive that has been transformed into a posture towards - ad - the eternal truth.

The Metaphorik of ownership and enslavement is of limited if not obsolete usefulness with this God of Augustine's, with his Holy Spirit who is paraclete, or 
comforter, and with a Son of God who came into the world and washed the feet of the lowliest of the Earth, himself manifesting a totally new conception of values and freedom through service. This is a god, expresses the man who in his youth had been 'in love with love' (Conf. 3.1), who wants to be elected out of a love which is its own reward, being its own pure motive. Augustine's is a religiosity of transformed human relations and transformed spiritual relationships, old meanings are renewed or revealed in their true fullness. Origins themselves and the selfevident, plain sense of things are converted: the New Testament has revealed the true meaning of the Old, just so does Augustine's Confessions present a man utterly changed who looks backward and inward and continues to try to make sense of himself and divine truth, through studying his inexhaustible self and its transformations. Augustine's life is a transformed meaning, just as the terms of its expression are subject to transformation.

Finding the true meaning of the old in the new truth, quoting the Psalms to disclose their fulfilment in the Gospels: this mystical process is at the heart of Augustinian interpretation. This typological mode of Augustine's is an essential key to understanding him and his writing, and perhaps we would do well to bring to our own interpretation or translation a commensurate sense of meanings as standing in complex, recursive relation through time. Tradition and transformation, like the facts of a life and its changing meaning over time, form a delicate and living dialectic. For translation, one may have thought it goes without saying, is interpretation not revelation, it is intrinsically midrashic and its most serious failure would consist in any disingenuous claim to be less of a failure than others through its privileged proximity or special access to some true, authentic, original meaning of the work.

Ruden wishes to retrieve for us the plain sense of servus and servire, as she does with dominus and indeed with Augustine, as I am arguing. A finer historicism is meant to return us to their meanings as Augustine would have understood them and defend us from the misleadingly 'more nuanced and less harsh constructions' of Eastern Mediterranean usages and the changing and distinct social world those reflect. Even if Augustine baulked as a child at learning Greek and had no Hebrew, he was scarcely isolated from a Mediterranean-wide community of letters and intellectual exchange. More importantly still, he had lived a life immersed not only in early acquaintance with Roman literature and rhetorical education and GrecoRoman philosophical culture but in intense readings of a Bible, which was itself a translation from Hebrew and from Greek into Latin and besides, the bible Augustine read, did not constitute a translation from the Hebrew, except if he later - reluctantly - may (or not) have used Jerome's Vulgate. Translation like Transformation - conversion - is at the very centre of Christianity, having the force of a principle. The complexities of translation, transmission, interpretation 
and their renewing, conversionary and modificatory effects are everywhere relevant in the intricate life and thought of Augustine.

\section{Hauling in a circle}

One may surmise that the major lines of Ruden's poetics of translation are as follows: she wants to make it new; restore the work to its original vividness; by a kind of etymological authority, retrieve the pristine sense of the language; while all along making a kind of homage to modernist liberty, such through the unconventional lay of type on page (see p. xxxvii ff. on her own 'compositional quirks', and the 'white space so useful in modern poetry' $\mathrm{p}$. xli and for regaining the oral cadences of Augustinian reading and delivery); and recovering the primacy of the immediate in poetic language, as opposed to the supposedly abstract or merely mental, as if the visceral and sensational had more ontic weight or authenticity here. Incidentally, this modern poetic alchemist's quixotic impulse to overcome the gap between the concrete, the sensational and the immaterial stuff of language and spirit is testified in a poem of her own making, 'Translators', with which she prefaces this work in her dedication.

As to the modernist liberties, many will agree that there is no problem in introducing anachronistic, non-traditional conventions for specific effect. Tradition, after all, is conserving as well as productively innovating. Everyone has a position, and there should, naturally, be nothing disqualifying in a reading of Augustine as of primarily aesthetic or literary-historical interest, the important early prose stylist of Coetzee's attention. To imply, however, one's own the uniquely right way of looking at him invites scepticism and if the argument is offered in a polemical fashion, more than scepticism it may elicit a critical scrutiny the polemical translator's position is not sufficiently developed to withstand.

We detect guiding principles, but it is not always entirely clear why Ruden has made the modifications she has. In that opening passage, for instance, the period 'et laudare te vult homo ... aliqua portio creaturae tuae' contains the repeated phrase aliqua portio creaturae tuae - 'a little piece of your creation', Chadwick; 'but a part of your creation', Hammond; 'but a tiny part of all that you have created', Sheed; 'a mere segment of what you have made', Wills. This phrase, epexegetically qualifying the subject homo, finds in the Latin a rhythmic alternation with the also repeated clause laudare te vult homo - 'man wants to praise you'. The careful modulation of rhythm in Augustine is lost in Ruden, who unaccountably varies the translation of the phrase and loses the repetition - "who is some part of what you created ... a given portion of your creation' - upsetting its clearly deliberate rhythmic patterning, and it is just so with laudare, which first is rendered 'praise' then shortly after 'extol'. 
The repetition 'circumferens suam ... circumferens sui' is not similarly marred by what may simply be an attempt at elegant variation or an instance of the 'flexibility' for which Ruden pleads, but her choice of 'hauling his deathliness in a circle, hauling in a circle the evidence of his sin" - compare "'bearing his mortality with him" (2 Cor. 4:10), carrying with him the witness of his sin', Chadwick; 'He bears about him his mortality, the evidence of his sinfulness', Sheed; 'even though humanity bears everywhere its own mortality, and bears everywhere the evidence of its own sin', Hammond; 'man, "confined by a nature that must die", confined by this evidence of his sin', Wills - again presents a serviceable example of what Ruden may be trying to achieve throughout this work. Her phrase is not in itself objectionable, in fact it has undeniable power. Its power may be just its problem however, for if it is vividness for the sake of effect it comes with a certain cost, rather like the baroque Hellenistic sculpture, which loses emotional force even as its artifice for effects of vividness escalates.

English 'haul' connotes a deliberateness and effortfulness about which 'carry around', 'bear' and the similarly colourless Latin 'circumferens' are neutral. 'Haul' is not simply 'carry a very heavy burden' but, surely, 'consciously be straining at pulling along some object'. Sisyphus hauls his rock, Odysseus hauls himself onto land, Simon hauls in his heaving nets on Galilee. This does not seem to be what humans do with their mortal natures, that is a different kind of burden, one that it is possible to be unaware of, that one can, through conversion of one's desires and values, simply release. It is an extraordinary, weightless and fatal burden, which one 'carries with one' from birth. It is, for Augustine, the emancipating burden through which humans can come to yearn for God and the delivery from this condition, transience and mortality.

'In a circle' for the 'circum-' element of the composite verb is an example of the etymological literalism, a maverick's pedantry even, which hinders rather than the opposite, straining too hard to make the reader experience, to really feel, the futility which is quite sufficiently expressed by 'carries around / bears everywhere his mortality'. Perhaps most surprising here is 'deathliness' for mortalitatem. English 'deathliness' is not quite the same thing as 'mortality'. An abstract noun formed on the adjective 'deathly', 'deathliness' is presumably an attempt to yield an English equivalent for the Latin formation of mortalitas 'mortality' on mortalis 'mortal' from mors 'death'. 'Deathliness' is unusual in English, if not downright odd. Why abandon the common 'mortality' for its sake? One suspects precisely because it is odd and because it is different from all those other translations. Originality is, of course, not in itself to be avoided, but neither is it in and of itself an absolute good, justifying all else. In an example like this, one sees how too much attention is drawn to the wording and choice of the translator in her obvious effort to be memorable and vivid and something of Augustine feels 
lost rather than regained. Like escalation in the nuclear arms race, the proliferation of new, more powerful poetic ordinance may lead simply to all round neutralization.

Returning to Ruden's glossary and specifically the term confessio and the English 'testimony', the Latin original of which - testimonium - we have seen recurring twice in the very carefully worded opening of the work: Ruden would prefer to call her translation of Confessions 'Testimonies' but is forced to 'retain this title just to keep my translation from being misidentified' (pp. xxxiii-iv). For Ruden 'confession' bears too heavily the implication of sin and the later Catholic rite of absolution, which it would not have done for Augustine and is thus undesirable. Augustine's work is an auto da fe, 'testimony' would express the 'strong judicial tinge' of the public declaration of faith, of which this text is a kind (p. xxxiv). It is certainly true that the range of English 'confession' is more negative and restricted than the Latin confiteor and confessio from which it derives. So, what is one to do with a word like confessio and more generally in a complex undertaking like this, in which some terms in Latin have a broader range than the usual English translation and some in English, by contrast, a broader range than the Latin originals?

When modern Confessions translators insist on the 'consistency' and 'discipline' of either translating a Latin single, traditionally established English one throughout this long work or footnoting exceptions, they are really talking about top-down, academically elaborated and enforced ideological and doctrinal consistency and discipline, which are much later than Augustine, and the imposition of which greatly frustrates his speaking with both perceptible religious fervour and authentic rhetorical ingenuity to a very broad readership in his time and beyond it. I appeal to professors who may be inclined to anathematize my translation because it is different from familiar ones: Would not Augustine have wanted flexibility? (p. xxvi).

Ruden pleads for slack. She wants flexibility in her alternating translations (praise ... extol), and she requires us to accept her versatility as she overcomes what is 'only a modern academic, rationalist take on him'. She promises to bring us into more direct contact with Augustine: 'A translator has to get beyond that to his inspired synthesis' (p. xxvii).

On these traductional 'headaches Augustine infuses into a translator' (as Ruden peculiarly puts it, p. xxvi) we could profitably compare another translator's approach. In the introduction to the first volume of her own recent translation Carolyn Hammond discusses the very problem of confessio (Hammond 2016: Vol. 1 pp. xviii-xix) and it is in her handling of the defeat to the occasional intractability 
of translating problems, a kind of intelligent surrender to semantic aporia, that one learns a kind of satisfaction in dissatisfaction, a productive surrender:

As a work, it defies categorization in terms of content; ... Part of the answer lies in the carefully chosen title: confessio means a declaration, either of belief, praise or sin - and the text is a commixture of all three. In his preaching Augustine made this explicit to his congregation: (Sermons 67.1). So, nuanced is his deployment of the term ... To substitute a variety of terms, such as 'declaration of praise' or 'affirmation of belief', would obscure for the reader this vital connective thread running through the text. (My italics).

A still more detailed discussion of 'confession' and confiteri is to be found in Foley's notes to the $2^{\text {nd }}$ edition of Sheed's translation (p. 329). This (beneficially) difficult Latin word translates the Hebrew psalmist's hoda(h) and Greek exomologeisthai. It includes the three senses registered by Hammond and Ruden, but Augustine, while presupposing these different nuances, writes Foley:

... also expands on the traditional notion of confession by more explicitly portraying it as a kind of sacrifice ... This development configures confession as a divinely initiated sanctifying transformation, and it underscores the relation between confession and the entire Christian mystery of death to the old man and rebirth in the new. Finally, it implies that Augustine is offering his Confessions as a sacrifice to God for the benefit of of the reader, specifically, for the purpose of effecting in the reader the same transformation.

At the level of the discrete term as well as the the broader project of the work, we find enlargement and transformation. Confessions is in one very real sense a reinterpretation of confessio. As well as being a complex activation of the Latin term's several denotations, the notion is modified in a thematic fashion by the writer whose spiritual transformation is recorded in a transformed language, one objective of which is also to transform others.

Ruden's wariness about the Catholic sacramental colouring of 'confession' and its emotional overtones of guilt is quite justified. But her handling of the difficulty is not made into an especially helpful opportunity for exploring the problem, as it is with other translators. Certainly, we have learned a lot more from Foley and Hammond than Ruden's unhappy resignation to convention and frustrated desire to replace confessio with 'testimony' ever let on could be the case. It is almost with Ruden as if there is in the name of a spurious historicity, some need to expurgate the sediments of Church and Catholic history that have 
accumulated over centuries, to deliver a humanist Augustine who 'can play dramatically with still clear physical meanings' (p. xxxiv) - a joyful player of semiotic games. And yet, Foley's example brings the term to life in a vital way. Confessio apparently forms part of a rich ecosystem of ideas and religious emotions and that is its Sitz im Leben, its context is not simply the context of historical, domestic or civic usage, it is not inert but activating new meaning, having a place in Augustine's, commemorative, therapeutic and transformative and not a lexico-realistic project.

What had seemed a problem, even a crisis in translation, becomes revelatory. It is a revelation of Augustine as extender of meanings, which is suppressed by the naïvist reading of Ruden's translation with its gung-ho dispensing of the theologians and scholars ('flexibility in word choice is an absolute necessity for literary faithfulness in translating this author ... I have to protest that patristics scholars have in general allowed anachronistic misunderstanding of both ancient writing and ancient Christianity to influence their dictates on what is proper' (p. xxv). It would be a shame were this freedom and creativity of Augustine's to be lost on the reader.

\section{4. 'I didn't love you, and I cheated on you like a true slut'}

There are many further examples, but they follow the same pattern of incommensurabilities between Late Imperial Latin and Modern English, Late Antiquity and the early $21^{\text {st }}$ century, Early Christianity and Post Enlightenment. We helplessly cover, for instance, Latin caritas, amor, diligentia with the overworked 'love' in English. In Book 8 Augustine describes the epiphany that precipitates his conversion, there appears to him Continentia, which Ruden wishes to render 'Self-control' again in the interests of an etymological purism, the expense of which may be the personficatory force of the name Continentia, to an English-speaker's ear. 'Abstinence', incidentally, is out of the question because for Americans this apparently is too politically loaded a term (pp. xxxvii-viii).

Vanus and vanitas are terms 'pounded by Ecclesiastes', present in translations only because of 'previous literary history', according to Ruden. They are for her misleadingly translated as 'vain' and 'vanity' (pp. xxxv-vi), when in fact they denote "“emptiness", "empty-headedness", "pretentious", etc., never "vanity" or "vain"”. Hammond, again, succinctly sums up the problem, the usage, the Hebrew terms in Ecclesiastes and Job, which the Latin translators chose vanus/ vanitas to do the work of and sensibly concludes that 'No single English word can express this range of nuance better than "vanity" itself" (Hammond 2016: Vol. 1 p. xix). In the translator's scales now the Latin is too semantically weighty, now the English outweighs the Latin, now the range of one is much wider, now the other: 
the languages are not flush. There is not, thank goodness, a perfect correspondence between them and we are richer for this generation of referents through the great multiplication of diverse signs across different languages. In these cases, 'previous literary history' is a help, not the mother of illusions to be effaced. That history is the record of established compromises, failures perhaps, but ones well illumined by scholarship whose consensus opinionis is not testimony to indifference or inertia, but optimal adaptation to the problems of an art inherently imperfective.

A selection of samples from Ruden, whose work we ought perhaps let speak more for itself. From early on one begins to get a sense of the latitudes the translator allows herself and a feeling that her project is essentially one to give Augustine a new tone, (which of course was, we are to understand, his very own original tone). Whether the translator's voice catches the tonality of Augustine or not, the following passage certainly seems to exemplify Ruden's own distinct voice, Conf. 1.15:

Is anyone's courage so great, because it clings to you with mammoth devotion [praegrandi affectu tibi cohaerens]; is there anyone, I ask — and come to think of it, a certain kind of cement-headedness [quaedam etiam stoliditas] could achieve this, so in fact there is someone - who in clinging to you reverently is so enormously devoted that he can pooh-pooh [ita parvi aestimet], in this grown-up manner, racks and hooks and similar devices for torture, panicked pleas to escape which rise to you from all over the earth?

In Book 1 Augustine is speaking of his youthful love of Roman Poetry and his ensnarement in erotic love, these in fact represent dereliction of God's true love, Conf. 1.21:

non te amabam, et fornicabar abs te, et fornicanti sonabat undique: 'euge! euge!' amicitia enim mundi huius fornicatio est abs te ...

I didn't love you, and I cheated on you like a true slut, and as I cheated there rang around me the words 'Excellent, excellent!' A 'loving' attachment to this world is cheating on you ... [Ruden]

I [not Aeneas] was the abandoner, the faithless lover, and my faithlessness earned the world's Bravo! Bravo! - since love of the world is abandonment of you, ... [Wills]

I did not love you, and by separating myself from you I prostituted myself; and as I prostituted myself the cry resounded from every side: 'Well done, well done!' For the love of this world is a physical infidelity to you, ... [Hammond] 
I did not love You and I went away from You in fornication: and all around me in my fornication echoed applauding cries, well done! Well done! For the friendship of this world is fornication against Thee: ... [Sheed]

I had no love for you and 'committed fornication against you' (Ps. 72: 27); and in my fornications I heard all around me the cries 'Well done, well done' (Ps. 34: 21; 39: 16). 'For the friendship of this world is fornication against you' (Jas. 4:4) ... [Chadwick]

With Ruden's 'like a true slut' and the thrice repeated 'cheated on you', we are in the familiar world of contemporary American human relationships, but are we still with Augustine in the world of such familiarised emotions, is there really such a correspondence; are the right things estranged in this translation and the rights one familiarised? We have lost the sense of philosophical and spiritual dimensions of relationship, developed through the invocation of Psalms and of the Epistle of James [ ' $\ldots$ know ye not that the friendship of the world is enmity with God? Whosoever therefore will be a friend of the world is the enemy of God.' Jas. 4.4. That itself in turn invokes the traditional Hellenic moral attitude of friends' enemies as my enemies, friends' friends my own friends]. This is not simply a selfdramatizing accusation of self as 'cheater', but forms part of a richly textured and highly developed conception of self, God and relation. It takes the comprehensibly human pattern and articulates something higher.

\section{5. 'Jagged and convoluted': On style}

Ruden has very definite opinions about Augustine's style and how the English translator should handle it (pp. xxii-iii):

His style ... is quite jagged and convoluted - but thematically so, and not in a way a translator should try to mitigate. She should instead hear the author saying, as he always does or more less explicitly, ' $I$ am not the guide for your minds; $I$ am not the proper object of praise or admiration. I write in this impressive way (as I was trained to do since early boyhood), but everything from my personal memories to my cosmic reflections is really just a joke - so I fill it with little jokes and keep explicitly backing off it to return to prayer and praise of God, where I started.' ... An objective, scientific tone is seldom warranted here.

Augustine is ventriloquised and, on this basis, we must dispense with 'scientific tone'. Here again is Augustine as blithe, literary joker whose objective is not articulating spiritual truth and whose interest for Ruden (and for her projected reader) is 'literary': 'But as his translator, I am more interested in Augustine as a 
literary figure than as a reporter ...' (p. xvii). The tone of the translator in her introduction prepares us remarkably well for the tone of the Augustine of the following translation. The pagan literature on which Augustine grew up was 'flashy': 'The brilliance, flashiness and subtlety of pagan literature' p. xvii, 'cosmopolitan flashiness' ( $\mathrm{p}$. xx). Augustine's account of his earlier life is racy in comparison with the exegetical and philosophical reflections of Books 10-13, forming a 'sexier life narrative' ( $p$. xix).

Augustine speaks, perhaps scandalously for the squeamish or the idealising, of nocturnal emissions and politically incorrectly refers to women as 'little women', (p. xxxix). Translators have glossed over his plain meaning, wishing he were not so frank but here is Ruden to repair these omissions.

As a partly folksy, sometimes smirking writer - or just as a man of his time - Augustine sometimes commits himself where his translators have wished he wouldn't, and this has led them to gloss over what he does plainly express (p. xxxix).

To many it will come as a great surprise to find Augustine characterised in this manner. At any rate, 'partly folksy, sometimes smirking, or just a man of his time' would make a pretty accurate blurb for this translation.

The account in Book 8 of Augustine's epiphany and conversion in the garden at Ostia is a high point of the work and of the whole canon. The taste for sound effects and a certain characteristic awkwardness (it is deliberately meant to convey the so-called 'jaggedness' of Augustine's Latin, we may surmise) but the momentum of the writing, towards the climax of the scene - a dramatic impetus which may be the main point — is diminished in Ruden's rendering, for example, Conf. 8.25:

So, I was sick and suffering horrendously, accusing myself more fiercely (or excessively more fiercely) than usual [solito acerbius nimis] and turning and churning in my chain [volvens et versans me in vinculo meo] until the last trace of it still holding me could be entirely torn off; but for me it held me nevertheless [donec abrumperetur totum, quo iam exiguo tenebar, sed tenebar tamen]. And within my secret self you stood over me, Master, [et instabas tu in occultis meis, domine] with your cruel mercy, stepping up the lashing [flagella ingeminans] of terror and shame, so that I wouldn't stop trying. If I did stop, that single tiny, wispy chain that remained [idipsum exiguum et tenue quod remanserat] wouldn't be broken; instead, its soundness would be renewed [revalesceret iterum], and it would bind me more sturdily. 
The translator's indecision at 'more fiercely (or excessively more fiercely)' is sloppy, an editorial oversight at best; the parenthesised alternative 'excessively more fiercely' will test the forbearance of even the most permissive reader of English. The Latin solito acerbius nimis could quite simply be translated as 'very much more fiercely'. 'Turning and churning in my chain' does mimic the alliteration of Augustine, although to some that may not be sufficient to excuse the tin-eared effect of this phrasing. '[B]ut for me it held me nevertheless' for tenebar 'I was held' is awkward. More significantly still, the delicate interplay in Augustine's account of activity and passivity and of a kind of reflexive middle state, of coming voluntarily to God and being driven on by a mix of feelings, of yearning and resistance expressed in the mix of passive and active verbs can be easily lost here in a translation not equal to the subtlety of momentum in Augustine's prose, which expresses so powerfully the gradual, tentative and pained flowering of the soul opening in conversion.

This is self-manumission from sin. Sin is of itself its own 'lashing', flagella, and consciousness of it is 'redoubled' pain, ingeminans. 'Thin and fine' exiguum et tenue - essentially hendiadys, becomes 'single tiny, wispy chain' in Ruden. It continues:

I was saying to myself inwardly, 'Okay, right now, I'm letting it happen, right now I'm letting it happen' [dicebam enim apud me intus, 'ecce modo fiat, modo fiat,']. Even as I spoke I was already starting to enter into the resolve. I was already - almost acting, and yet I wasn't acting [iam paene faciebam et non faciebam] ...

He is almost beginning to do it, to make the step: the sense over these passages is of the deep seriousness, the astonishing and utterly plausible commingling of agonizing and yearning longing. Augustine is a man of hesitations and deep thoughtfulness; his writing is the very instance of this nature. Further on we follow this so very delicately chronicled process:

I was hanging back from dying to death and living for life [haesitans mori morti et vitae vivere]. For me what was worse was stronger, because it was deeply inculcated, than what was better, because I wasn't habituated to the latter [plusque in me valebat deterius inolitum quam melius insolitum]. The nearer to me that moment moved at which I was to become something different, the more it struck terror into my heart. But it didn't strike me back or turn me to the side; it just left me dangling there [sed non recutiebat retro nec avertebat, sed suspendebat].

Ruden's salient 'living for life' for vitae vivere in this famous passage, bears the unfortunate colouring of the contemporary self-help maxim. Contrast it with 
Watts' 'to die unto death, and live unto life' (also Sheed); or Hammond's 'dying to death and living to life' (also Chadwick).

Since Ruden is primarily interested in Augustine as 'literary artist', it is surprising how she will pass over in silence his playing with words. At the opening of Book 3 he puns on Carthago, 'Carthage'/ Sartago, 'cooking pan'. It is probably impossible to express this pun identically in English. Hammond makes Carthage a seething 'melting pot of illicit passions', Sheed gives the witchy 'a cauldron of illicit loves boiled about me', and explains the pun in a note. Where Hammond evokes the promiscuity of farrago and Sheed the spiritual deviance of dark magic, Ruden seems above all to value the immediacy of the domestic detail and the opportunity for sibilant alliteration: 'I came to Carthage, to the center of a skillet where outrageous love affairs hissed all around me'. Similarly, in the passage above, in the well balanced deterius inolitum quam melius insolitum, there is paronomasia of which we have no hint in Ruden's choppy English: 'For me what was worse was stronger, because it was deeply inculcated, than what was better, because I wasn't habituated to the latter'. Inolitum is something like 'ingrown' and insolitum 'unaccustomed'. To be fair, she could not be expected to signal every nuance of the Latin, but any 'jaggedness' here is with her and not in fact in Augustine. Compare Sheed's 'The lower condition which had grown habitual was more powerful than the better condition which I had not tried', although necessarily more extended than the marvellously compact Latin, this preserves some of the rhythmic feel of Augustine's elegant phrasing.

With Ruden we are promised the authentic, fun Augustine, a joking Augustine with a sexy backstory (even if he does lapse into high abstraction and biblical exegesis after the ninth book) and an habitual smirk, not a 'plodder or systematizer' but a 'poetic, organically branching, rather whimsical author'. Other translators have given us a far more nuanced, more interesting Augustine, one marked by much more creatively exciting tensions than Ruden's sub-Nabokovian, literary joker.

\section{In aenigmate: Dark figures}

Augustine is strange to himself, an enigma which he sees, as into a glass darkly. How then will we, also mysterious to ourselves, ever have the last word on what he meant? In the chapter on Confessions in his acclaimed life of Augustine, Peter Brown discusses Augustine on his own opaqueness to himself, the problem presented of being made up of a seemingly limitless inner landscape, much of which was dark to his own surveying conscience. There is for Augustine,

Brown 2000 [1967]:172-3. 
especially in comparison with the Neo-Platonist Plotinus' luminous imagining of the mind, a 'murmurous region' a darkness adumbrating the bright consciousness, which too for the African constitutes himself, Conf. 10.16.25 (here in Brown's own translation of quoted passages in his Augustine of Hippo - A biography):

This memory of mine is a great force, a vertiginous mystery, my God, a hidden depth of infinite complexity: and this is my soul. And this is what I am. What, then, am I, my God? What is my true nature? A living thing, taking innumerable forms, quite limitless ...

For there is in me a lamentable darkness in which my latent possibilities are hidden from myself, so that my mind, questioning itself upon its own powers, feels that it cannot rightly trust its own report (Conf. 10.12.48).

Here is the true modernity and originality of Augustine, one may feel, far more so than in some putative sense of his free play of signs or as cosmopolitan manipulator of language as an elaborate, 'literary' joke who simply marshals a 'flashy' education in rhetoric in service of a new master. Long before Freud, 1200 years before Shakespeare, this complex, extraordinarily sensitive, Romanised African thinker marvelled how 'there is in man an area which not even the spirit of man knows of' (Conf. 10.5. 7).

The critic Frank Kermode once published a short and brilliant essay in a volume of the same title, called 'The Uses of Error'. The history of reading the Bible and translating it is in one real sense a history of productive misprision, he argues. He demonstrates this with the case in Saint Jerome's Vulgate of a mistranslation from the Hebrew of 'curse'/ 'bless' in the Book of Job and traces the ramification of the error, which becomes in English the established and famous utterance of Job's wife 'Curse God and die'. As Kermode wrote:

The history of interpretation, the skills by which we keep alive in our minds the light and dark of past literature and past humanity, is to an incalculable extent a history of error. Or perhaps it would be better to say, of ambiguity, of antithetical senses ... We have always been pretty sure that the literal sense is not enough, and when we try to go beyond it we may err, but sometimes splendidly. ${ }^{8}$

As with self so with scripture and its translation: there is always a certain measure of ignorance, misunderstanding and error. Out of ambiguity and even out of antithetical senses, not simply dogmatic cleaving to what we may claim to be the authentic literal sense, we may chance upon new light. Through the cracks of sin

Kermode 1991:431. 
and error we learn that there may issue the splendour, for the secular critic, of meaning; or for the Christian studying the significance of their fallenness and desire for redemption, of divine Truth.

The translation and continual re-interpretation of certain kinds of works those works, classics, which endure because, in Kermode's defining phrase, they are 'patient of interpretation' - represents a kind of opportunity for error of a certain profound kind. Tradition and interpretation in complex dialectic enrich one another in a perpetual motion of intelligence and feeling.

It is part of our experience of the past that we change it as it passes through our hands; and in changing it we may make it more puzzling in making it more our own. ${ }^{9}$

We are changed by what we study and it changes us and even reconstitutes us. This is surely a humbling fact to recognise. There is always that in works, as in ourselves, to which we have not access, or only in the most oblique ways.

We bring ourselves and our conflicts to words, to poems and pictures, as we bring them to the world; and thus, we change the poems and the pictures, or perhaps it is ourselves we change. ${ }^{10}$

We require great works and we require great interpretations and gifted interpreters in order to live more deeply. The sense of poems and pictures and novels does not lie open and plain for all to see, for sense never does, but is always something sought. ${ }^{11}$

In this seeking, we rely on Augustine and the scholars who following him continuously reconstitute his meanings as tradition, just as the faithful rely on their praedicantes to illuminate the readings of scripture and their unapparent meanings. We ought to feel gratitude for the great fortune to live in this age of scholarship, which provides precious consolation for the shallowness and crudeness of a deceptively accessible contemporary public discourse, with its platforms and sensationally memorable language devised by marketers and purveyors of larger than life personality. If we only seek, the fascination and the meanings of history are there to rediscover. If we truly will it, we find many ways into great writers are opened to us by accomplished and generous scholars.

Augustine opened his work, as we saw, with searching questions about the knowledge of God and the recognising him rightly, that fundamental problem that

9 Kermode 1991:429.

10 Kermode 1991:432.

11 See on this topic also Kermode's essay 'The plain sense of things' in An appetite for poetry, 1989. 
besets believing human beings and those who yearn for belief. He closed his Confessions, as ever expecting us to recognise the reference to Scripture (Matthew 7:7-8) and to the opening of his own Books 1 and 12, with three elegantly modulated sets of three refrains. O'Donnell in his commentary points out 'the shift from subjunctive [in Books 1 and 12] to the indicative future' here, 'marking the surety of the promises' in Hammond's phrase. Confessions has been a great development, expressed in many subtle ways. It is a fine sphragis or seal on this great work, which will for more millennia still richly reward the closest study. Here is Augustine's ending with Hammond's fine English rendering, Conf. 13.38.53:

et hoc intellegere quis hominum dabit homini?

Quis angelus angelo?

Quis angelus homini?

A te petatur,

In te quaeratur,

Ad te pulsetur:

Sic, sic accipietur,

Sic invenietur,

Sic aperietur.

What human being can give another the power to

Understand this?

What angel can give it to another angel?

What angel can give it to a mortal?

We must ask it of you.

We must seek it from you.

We must knock at your door.

This, this, is how it will be received.

This is how it will be found.

This is how it will be opened.

\section{Conclusion}

Despite the foregoing reservations expressed, it must be said that Ruden's work should be welcomed as a contribution to the study and, perhaps more importantly, the popularising of Augustine's work as quite simply great reading. As readers we will naturally cultivate personal tastes and retain different views about translation. It is precisely this (ideally) judicious and fair-minded mutual assessment, this disputed reception, which serves so well as a means to keep alive and re-articulate the vitality of great works from the past. 
Ruden's strong, prefatory claims invite special scrutiny from a reviewer. Just because one's attitude, expectations and techniques are those of a scholar reader does not mean that one should be disqualified, denied as a mere Casaubon, incapable of being with it. Discerning in Augustine a different tone than that a new translator does is not necessarily tantamount to an unreadiness to embrace new positions or fresh takes. Equally, just because one claims to be innovative and maverick, it does not mean that when readers do not find that your arguments always stand up to scrutiny or compare well with others, that this is because they are conservative and on principle against innovation and new approaches. We must always hope for brave, searching, new interpretations and hope to be equal to the challenge of revising our vision of the past and of the works we cherish.

New translations, which is to say new interpretations, ought to be taken very seriously and carefully considered in comparison with other, previous translations and the original language of the text and not, of course, only on the basis of the claims made by the translator. We ought to hope that Ruden's work will find its way not only to established lovers of literature and of Augustine, but to many new readers and that through it they will find their own way to an ever richer and more rewarding experience of classic works such as Augustine's Confessions.

\section{BIBLIOGRAPHY}

Brown, P 2000 [1967]. Augustine of Hippo: A biography. Berkeley \& Los Angeles: University of California Press.

Kermode, F 1989. The plain sense of things. In An appetite for poetry. Kermode, F, Harvard University Press.

Kermode, F 1991. The uses of error. Harvard University Press.

Lane Fox, R 2015. Augustine: Conversion to Confessions. Basic Books. Ruden, S 2017. Augustine: Confessions. New York: The Modern Library.

Sheed, F 2006. Augustine - Confessions. Indianapolis / Cambridge: Hackett Publishing Company. 